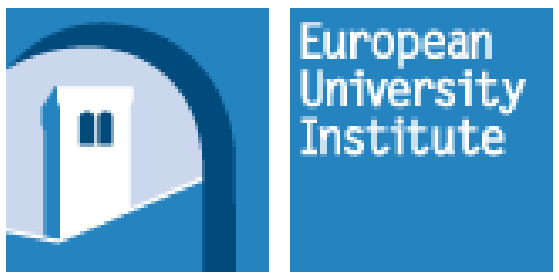

European Journal of Legal Studies

Title: The Functionality of Conceptual Terms in International Law and International Legal Discourse

Author(s): Ulf Linderfalk

Source: European Journal of Legal Studies, Volume 6, Issue 2 (Autumn/Winter 2013/14), p $27-50$

\begin{abstract}
:
Investigating the meaning of conceptual terms is an important task for legal scholars. Traditionally, the meaning of conceptual terms has been analyzed by reference to what those terms describe, namely a relationship between, on the one hand, the particular properties identifying a particular phenomenon or state of affairs as belonging to the extension of a concept, and on the other hand, the legally relevant inferences ensuing from the categorization. While this theory works reasonably well as long as studies are confined to the meaning of conceptual terms in law, it is ill-suited for any similar study of international legal discourse. In the search for workable alternatives, this essay adopts a different approach. It equates the meaning of a conceptual term with its functionality, ie with what the uttering of a conceptual term potentially does to the beliefs, attitudes, and behaviour of participants in a legal discourse. The essay illustrates the many important further implications of this theory of meaning for the analysis of international legal discourse.
\end{abstract}




\section{The Functionality OF CONCEPTUAL TERMS IN INTERNATIONAL LAW AND INTERNATIONAL LEGAL DISCOURSE}

Ulf Linderfalk *

TABLE OF CONTENTS

1. INTRODUCTION 29

2. AN INTRODUCTION TO A FUNCTIONALITY-BASED THEORY OF MEANING

3. THE ECONOMIZING FUNCTIONALITY OF CONCEPTUAL TERMS33

4. THE NORMATIVE FUNCTIONALITY OF CONCEPTUAL TERMS.... 36

5. THE CAMOUFLAGING FUNCTIONALITY OF CONCEPTUAL TERMS 39

6. THE DISCLOSING FUNCTIONALITY OF CONCEPTUAL TERMS ... 41

7. THE SYSTEMIZING FUNCTIONALITY OF CONCEPTUAL TERMS 42

8. THE FORMATIVE FUNCTIONALITY OF CONCEPTUAL TERMS ... 44

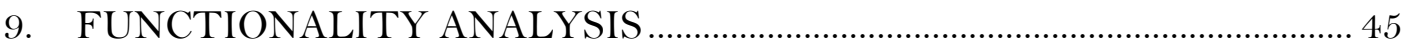

10. ON THE USEFULNESS OF FUNCTIONALITY ANALYSIS ..................... 47

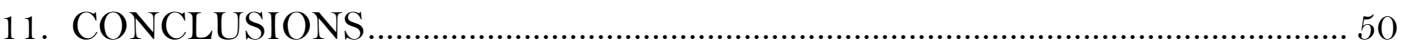

* Ulf Linderfalk is Professor of International Law at the Faculty of Law, Lund University, Sweden. He wishes to extend his sincere gratitude to Dr Olof Barr, a mathematician and philosopher, and a great pal and discussion partner. Special thanks go also to the Institute for Legal Scientific Research (Institutet for rättsvetenskapligforskning), as well as to the Ragnar Söderberg Foundation, for the financial support needed to complete this article. 


\section{INTRODUCTION}

This essay focuses attention on the language used in legal discourse. More specifically, it focuses attention on a particular element of legal language, namely the set of conceptual terms that it entails. For the purposes of the present essay, a concept is a mental representation. ${ }^{1}$ It is the generalized idea of an empirical or normative phenomenon or state of affairs (eg the king of Sweden, the Quran, the colour grey, sovereignty, the coastal state jurisdiction of Denmark in the Baltic Sea, or the diplomatic relations of Syria with Turkey) or a class of such phenomena or states of affairs (eg lions, BMW motorcars, international waters, commercial transactions, diplomatic immunities, or belligerent occupation). ${ }^{2}$ A conceptual term is a term, like any of the examples just provided, used for the verbal representation of a concept.

Scientific disciplines such as cognitive science, psychology, and the philosophy of mind have long emphasized the importance of concepts for cognitive processes such as perception, reasoning, and understanding. ${ }^{3}$ While potentially, different concepts may often be used to represent a phenomenon or state of affairs, depending on the concept or concepts actually drawn upon in the mental processing of an observation of such a phenomenon or state of affairs, human beings will understand it differently. ${ }^{4}$ Consequently, conceptualizing a phenomenon as a car rather than a leisure car, typically, people will draw different inferences about the phenomenon. Similarly, people will draw different inferences depending on whether they conceive of a phenomenon or state of affairs as a dog or a pet, as a wine or an alcoholic beverage, as grey or as Hex Triplet B2BEB5, as a religious practice or a cult, as a targeted killing or an extrajudicial killing of an unlareful combatant, as summer or the time period from 1 June to 31 August, as a reasonable decision or a decision based on rational argument, and so on and so forth.

Granted that perception, reasoning, and understanding are a necessary and important part of the way lawyers think and talk about law, such observations raise attention to the usage of conceptual terms in legal discourse. Obviously, it makes a difference whether a legally relevant phenomenon or state of affairs (eg a taking of property, or the exercise by Norway of enforcement jurisdiction in the Barents Sea), or a class of such phenomena or states of affairs (eg jus cogens, or foreign armed occupation), is referred to by lawyers using the one conceptual term or the other. What then is this difference? Stated in terms of one of the examples, what does the uttering of jus cogens help communicate that cannot be communicated by uttering instead a term such as the international ordre public?

To address such questions properly, lawyers would have to draw on some particular theory of meaning. A theory of meaning is implied in any study of verbal communication, whether in the context of legal discourse or just any community of people using a language. If jus cogens can be used to communicate something that the international ordre public cannot, then this difference can be captured only by referring to the different meanings of the two terms.

In the legal literature, commentators have generally analyzed the meaning of conceptual terms by reference to what those terms describe. This was the point of departure of the

\footnotetext{
1 On the ontology of concept, see eg Eric Margolis and Stephen Laurence, 'The Ontology of Concepts: Abstract Objects or Mental Representations?’ (2007) 41 Noûs 561-593.

2 Compare Birger Hjørland, 'Concept Theory', (2009) $60 \mathrm{~J}$ of the American Society for Information Science and Technology 1519-1536.

${ }^{3}$ For an overview of some of the core readings on this topic, see Eric Margolis and Stephen Laurence, Concepts. Core Readings (MIT Press 1999).

${ }^{4} \mathrm{cf}$ Hjørland (n 2).
} 
Danish legal philosopher Alf Ross, whose writing in the 1950's introduced the topic on the agenda of legal scholarship, ${ }^{5}$ and it has permeated much of the thinking of lawyers since. In this essay, I will approach the issue from a different angle. I will adopt the theory of meaning first suggested by philosophers like John L Austin and John Searle, ${ }^{6}$ and later developed by modern pragmatics. ${ }^{7}$ This theory recognizes that utterances do not just describe, but potentially do also a variety of other things. If Jane, in addressing John on his way out, utters 'It's raining!', the meaning of this utterance cannot be fully captured by the interpretation that Jane describes the current weather conditions. Depending on the particular context or situation of utterance, potentially, an utterance like Jane's may also be used to cause John to think that maybe he should bring an umbrella; it may be used to cause John to think that maybe he does not need to water the plants in the garden (as he suggested he would earlier this morning); it may be used to cause John to think that maybe he should offer Jane a lift to work; it may be used to cause John to think that maybe he should help Jane move tables from the garden and lay them inside (while she is planning a garden party later that day); etc.

The point of departure chosen for this essay implies that the usage of conceptual terms in legal discourse can be analyzed in very much the same way as sentences such as It's raining!. Consequently, throughout the essay, I will equate the meaning of legal utterances with their functionality. The functionality of a conceptual term in a legal discourse is what the uttering of the term potentially does to the beliefs, attitudes or behaviour of participants of that same discourse. ${ }^{8}$ I will refer to this as a functionality-based theory of meaning. The competing theory advocated by Professor Alf Ross and his followers will be referred to as the descriptive theory of meaning.

It is the purpose of this essay to illustrate the further implications of a functionality-based theory of meaning for the analysis of legal discourse. Although I see no reason why this theory should not be applicable to legal discourse generally, since international law is my preferred field of expertise, I will confine treatment to international legal discourse. The organization of the article will be as follows.

In section 2 , by contrasting a descriptive and a functionality-based theory of meaning, I will give a description of some of the basic features of the latter. Having done this, in section 3-8, I will start exploring the further implications of a functionality-based theory of meaning for an analysis of the meaning of conceptual terms in international legal discourse specifically. I will do so relative to particular examples. The examples will give the theory a more concrete shape, and they will provide crucial insights that prepare the ground for the subsequent sections 9 and 10. As sections 3-8 will illustrate, conceptual terms have a number of different functionalities. Functionalities derive from such things as the complexity of law; the inherent nature of concepts; the dependency of international legal language on the language used for the communication of normative propositions in contexts other than international legal discourse; and the systematic organization of conceptual terms. In section 9, I will suggest a methodology that may be used for the determination of the functionality of particular conceptual terms in legal discourse. Throughout this essay, I will refer to this methodology as functionality analysis. In sections 10, finally, I will inquire briefly into the usefulness of functionality analysis. As I will argue, if international lawyers

\footnotetext{
${ }^{5}$ See Alf Ross, 'Tû-tû', (1956-1957) 70 Harvard L Rev 812-825.

${ }^{6}$ See John Langshaw Austin, How to Do Things With Words (Clarendon Press 1962); John Searle, Speech Acts (CUP1969).

${ }^{7}$ For an excellent, easy-to-read introduction to the topic, see eg Stephen Levinson, Pragmatics (CUP1983); Diane Blakemore, Understanding Utterances (Blackwell 1992).

${ }^{8}$ cf John Lyons, Semantics (CUP 1977) 725; Blakemore (n 7) at 102-103.
} 
can come to realize and accept the functionality dimension of legal meaning, and they also have tools to determine the functionality of particular conceptual terms, this may advance international legal analysis in many areas of investigation. For example, it will help international lawyers explain and critically assess international legal discourse generally. Moreover, and perhaps more importantly, functionality analysis will allow international legal scholars to explain the significance of international legal discourse; thus it will enhance also their understanding of important legal activities, such as for instance the formation of international law.

\section{AN INTRODUCTION TO A FUNCTIONALITY-BASED THEORY OF MEANING}

Concepts work as 'intermediate links' in legal inferences. ${ }^{9}$ In his pioneering article, Professor Ross illustrated this proposition using the concept of legal ownership. He noted that in Danish law - like in most domestic legal systems - legal ownership in a piece of property can be accomplished in several different ways: for instance, by purchase, by inheritance, and by the occupation of res nullius. ${ }^{10}$ Similarly, in Danish law, the acquisition of legal ownership in a piece of property has several different legal consequences. For instance, the lawful owner of a piece of property will normally be at liberty to sell it. The lawful owner of a piece of property will normally be allowed to use it as security for a loan. The lawful owner of a piece of property will be entitled to claim compensation if the property is culpably damaged by acts of other people. He or she will normally be at liberty to bequeath it to another person by legacy. ${ }^{11}$

According to Professor Ross, if we venture a description of the concept of legal ownership in Danish law relative to some particular person $(\mathrm{NN})$ and some particular piece of property $(\mathrm{P})$, consequently, the description would come out something along the following lines:

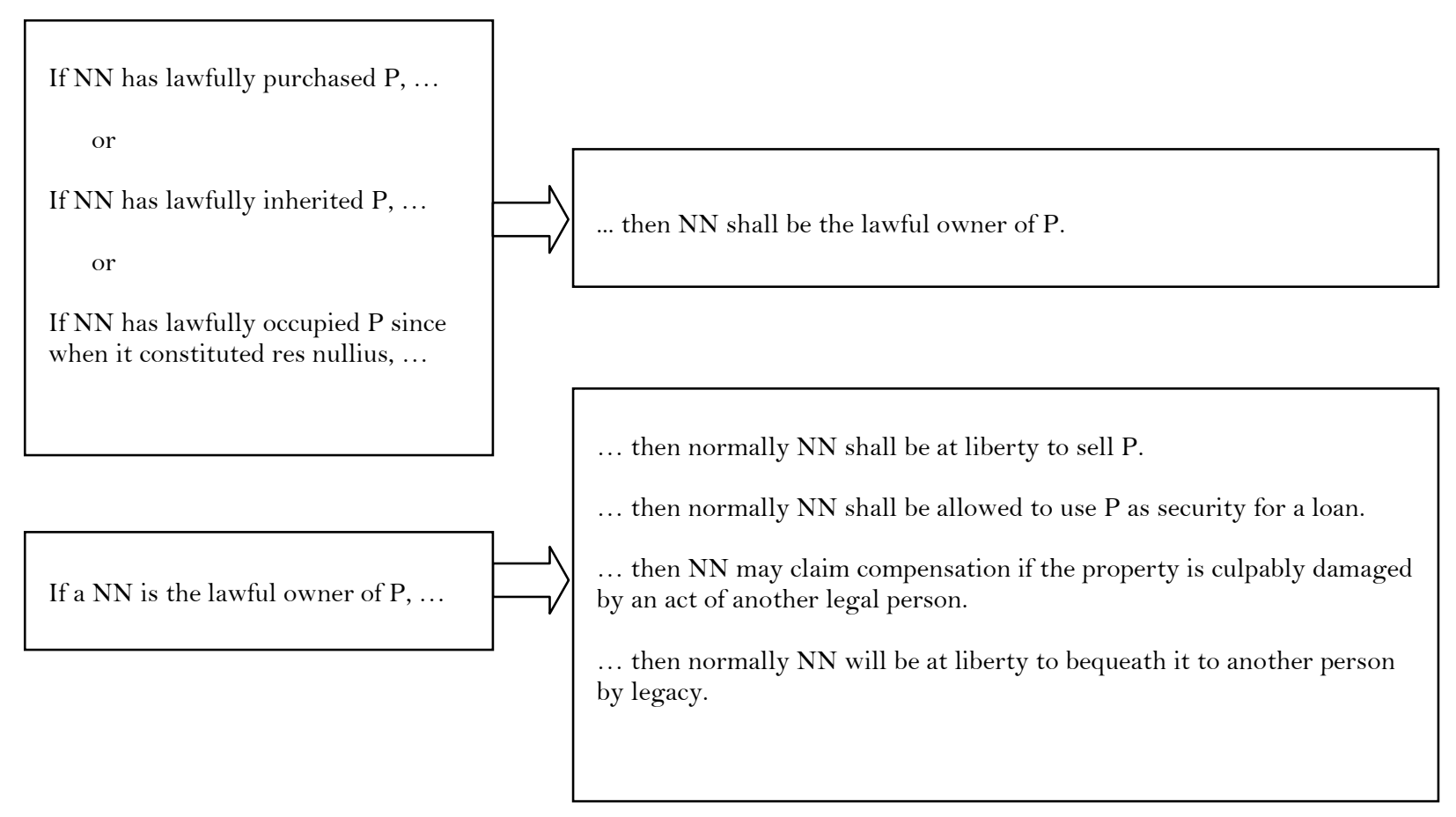

\footnotetext{
${ }^{9}$ Ross (n 5) at 821.

$10 \mathrm{ibid}$, at $817-819$.

11 ibid, at 817-819.
} 
As can be seen from the scheme, on the one hand, legal ownership is a link to the particular properties identifying a particular state of affairs as the legal ownership held by the particular person NN in the particular piece of property $\mathrm{P}$. Henceforth in this article, properties of this kind will be referred to as identifying criteria. On the other hand, legal ownership is a link to the legally relevant inferences ensuing from the characterization of a particular state of affairs as the legal ownership held by the particular person $\mathrm{NN}$ in the particular piece of property P. Henceforth in this essay, such inferences will be referred to as legal consequences.

The idea of concepts as intermediate links in legal inferences serves as a necessary background to the theory of descriptive meaning advocated by Professor Ross and many others. According to this theory, conceptual terms describe a relationship between identifying criteria and legal consequences. ${ }^{12}$ This relationship determines the meaning of conceptual terms in legal discourse. Consequently, any question concerning the meaning of a term like legal ownership can be answered by reference to its role in inferences from identifying criteria to legal consequences. When asked to define the meaning of an utterance of a term such as legal ownership, if we provide a scheme similar to that given in the previous paragraph, this will be fully sufficient. ${ }^{13}$

It is the main flaw of this suggestion that it totally ignores the importance of a very large portion of legal discourse. As known by every lawyer, people may engage in legal discourse for a variety of different purposes. To illustrate, take again the concept of legal ownership expressed as a general relationship held between the identifying criterion 'If a person has lawfully inherited a piece of property' and the legal consequence 'then normally this person shall be at liberty to sell it.' Obviously, participants in legal discourse may assert the existence of this law, but they may also challenge its existence; they may practice and uphold the law; they may approve it, criticize it, construe it, explain it, and suggest its revision. Furthermore, assuming that the law in question does not already exist, participants in legal discourse may either suggest its adoption or they may advice against it. In assuming that conceptual terms have no meaning independently of their role as intermediate links in legal inferences, it would seem proponents of the descriptive theory of meaning are concerned with legal discourse only to a limited extent. Contrary to the pretensions of most proponents, the theory of descriptive meaning should not be seen as a general thesis about the meaning of conceptual terms in legal discourse. It should be seen as a theory about the meaning of such terms in the limited context of assertions about the lex lata.

For this reason it is my suggestion that the meaning of conceptual terms in international legal discourse be analyzed, not in accordance with the theory of descriptive meaning represented by the writing of Alf Ross and others, but in accordance with the theory of meaning advanced by modern pragmatics. As argued by pragmatics, using language is to engage in social inter-action. When a person makes an utterance it is in the expectation that it will influence, in some way or another, the beliefs, attitudes, or behaviour of the addressee or addressees. ${ }^{14}$ So defined, pragmatics can certainly accommodate for the limited aspects of language use emphasized by the descriptive theory of meaning. According to the descriptive theory of meaning, by the uttering of a conceptual term, participants in international legal discourse describe a relationship between identifying criteria and legal consequences. The description is presented by the utterer as true. Rephrasing this in a terminology better

\footnotetext{
12 ibid, at $822-823$.

13 ibid.

${ }^{14} \mathrm{cf}$ Lyons (n 8) at 725.
} 
suited for pragmatic analyses, pragmatics would say that utterances are assertions. The usage of conceptual terms potentially helps convince participants in international legal discourse of the existence of some certain relationship between identifying criteria and legal consequences.

Pragmatics being a broader approach to language use than the descriptive theory of meaning, naturally, a functionality-based theory of meaning goes further than this. It recognizes that although utterances may be made for the purpose of the transmission of descriptive information, an utterer may not always be fully committed to the truth of a description. ${ }^{15}$ To illustrate, a law student may exclaim after having failed twice the international law exam: 'I'll never get to understand international law.' The student may mean this as an assertion. More likely, however - since the student talks about a future that is partly beyond his control - he will mean his utterance as an assumption or a conjecture. Furthermore, a functionality-based approach recognizes that even though an utterance may be made for the purpose of describing some certain phenomenon or state of affairs, description is rarely (if ever) the sole purpose of an utterance. ${ }^{16}$ Take the following utterance made by John addressing Jane over the phone: 'I wish you were here.' In one interpretation of the utterance, it describes a particular state of affairs, namely the fact that John wishes that Jane was with him. However, the utterance is made also with the clear expectation of some certain reaction on the part of Jane. Most likely, the aim of John is to make Jane feel that she is being longed for, desired, or loved. If Jane for some reason fails to capture this part of John's message, she will miss an important aspect of the meaning of the utterance.

It should be noted that there is no one-to-one correspondence between the grammatical structure of an utterance and what the utterance potentially does to the beliefs, attitudes, or behavior of the addressee or addressees. ${ }^{17}$ This is illustrated by the earlier example of Jane addressing John on his way out: 'It's raining!'. Grammatically, Jane's utterance is a declarative sentence, but obviously, a sentence like this may be used for other purposes than just describing the prevailing weather conditions. For example, it may be used to warn John that he runs the risk of getting wet. For this same reason, the functionality of an utterance is not dependent on the use of the grammatical verb. ${ }^{18}$ The utterance by a person of a piece of language may influence the beliefs, attitudes, or behaviour of an addressee, although the utterance has no verb at all. For example, if one of my colleagues entered my office exclaiming 'What a mess!', I would probably feel embarrassed or even a bit ashamed. I see no reason why the functionality of conceptual terms, which are typically nouns, should not be equally independent of the grammatical verb. This is why I venture the suggestion that there are other aspects of the meaning of a conceptual term in legal discourse than just the description conveyed of a relationship between identifying criteria and legal consequences. In the subsequent sections 3-8 of this essay, I will explore this idea further, providing illustration of some of the many functionalities of conceptual terms in international legal discourse.

\section{THE ECONOMIZING FUNCTIONALITY OF CONCEPTUAL TERMS}

In his 1957 article, Professor Ross commented on the usefulness or 'function' of conceptual terms. He argued that since concepts work as an intermediate link between identifying

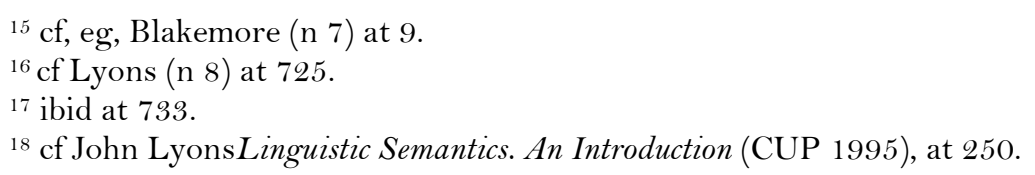


criteria and legal consequences, they serve also as 'a technique of presentation'. ${ }^{19}$ Professor Ross illustrated this proposition using the example of Danish property law reiterated earlier in this essay. ${ }^{20}$ If we choose a description of Danish property law relative to some person $(\mathrm{NN})$ and some particular property $(\mathrm{P})$, linking single conditions for the application of the law with the inferences that ensue from its application, the description will amount to twelve separate rules:

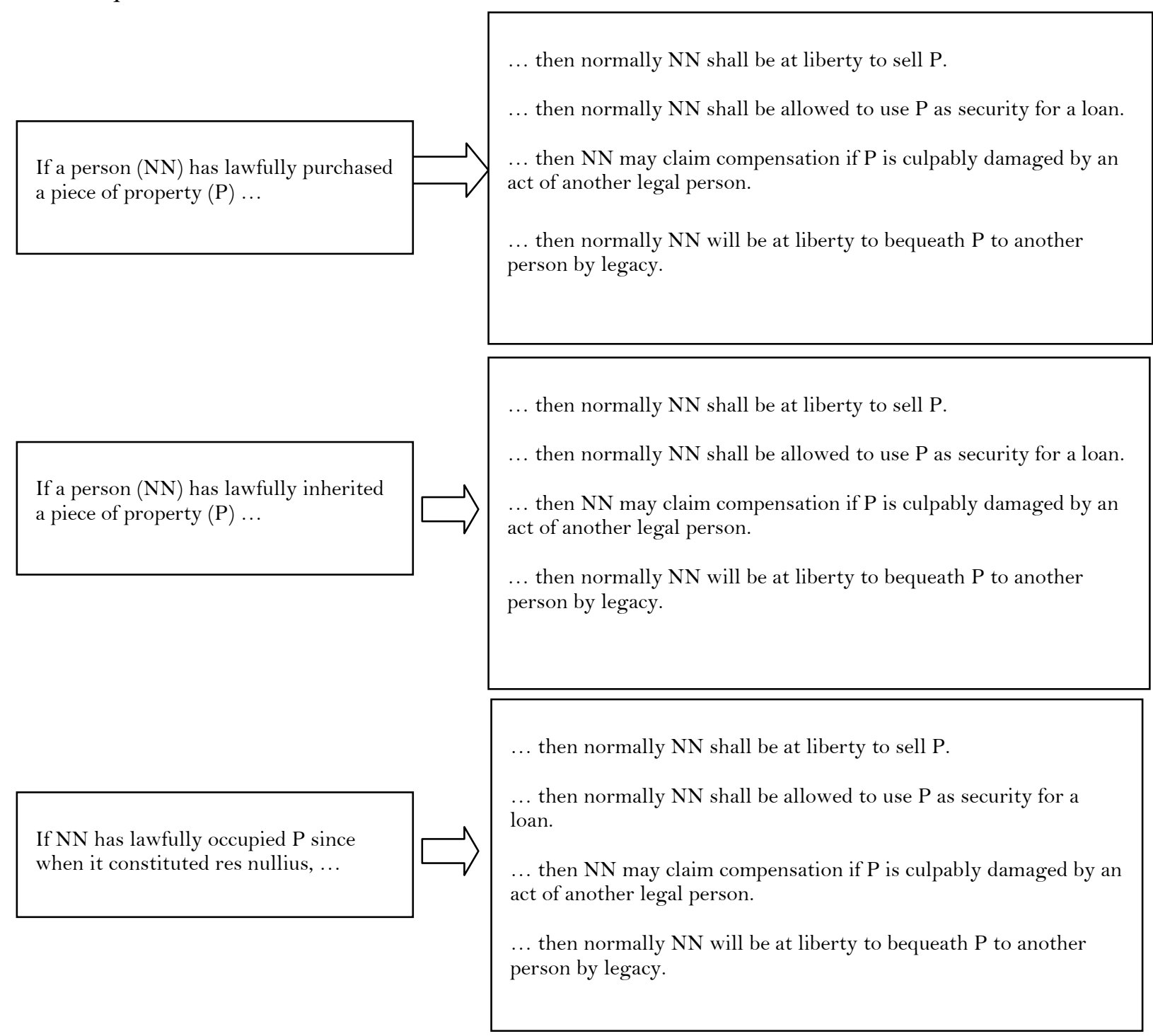

As illustrated by the alternative scheme in section 2, our description will be considerably shortened if instead we decide to express the law using the concept of legal ownership as an intermediate link. The number of rules will now be merely seven. Stated in cold figures, by drawing on the concept of legal ownership, we will have reduced our statement of the law by something like 42 percent.

Surprisingly, by suggesting that conceptual terms not only describe but also economize verbal statements of the law, Professor Ross comes very close to a functionality-based theory of meaning. Certainly, his idea of conceptual terms as techniques of presentation can be accommodated by this theory. It would then have to be slightly modified, however. To say that conceptual terms serve as a technique of presentation is to say that the uttering of

\footnotetext{
${ }^{19}$ Ross (n 5) at 822.

20 ibid at 819-824.
} 
conceptual terms affects the way people think and talk about law. What makes this suggestion slightly problematic is its concern with the function of conceptual terms rather than their functionality.

As indicated in section 1, this essay focuses attention on the meaning potential of conceptual terms in international legal discourse. In line with modern pragmatics, in this essay the meaning potential of a conceptual term is equated with the functionality of that term, i.e. with what the uttering of the term potentially does to the beliefs, attitudes, or behaviour of participants of international discourse. To understand this approach properly, we must be careful not to confuse the meaning potential of an utterance with its actual function or effect. ${ }^{21}$ The meaning potential of an utterance may help communicating a certain message, but it will never by itself determine the way the utterance is being understood by an addressee. To illustrate, let us assume that Jane utters to her husband John, who is on his way out: 'It's raining!' Jane wishes to cause John to think that perhaps he should bring an umbrella. Potentially, her utterance may have this effect, but there is no guarantee that John will actually capture the intended message. If, for instance, Jane is throwing a garden party later that day, John may well understand Jane to be suggesting that he help move tables from the garden and lay them inside.

The example illustrates the difference between the functionality of a piece of language like It's raining! and the actual function or effect of its utterance. The difference lies in the absence or presence of a particular context. If we talk about the functionality of a particular conceptual term, we may do so without having specific regard to any particular context of utterance. If we talk about the particular function of the utterance of a conceptual term, we may not. In the example of John and Jane, the effect of Jane's utterance cannot be explained without considering the assumption or assumptions that John bring to bear on the process of understanding it, ${ }^{22}$ in this case the assumption that Jane is throwing a garden party later that day.

This is the reason for why I have difficulties accepting unreservedly Ross' idea about the economizing function of conceptual terms. His suggestion that the uttering of conceptual terms will always affect the way a particular participant in international legal discourse thinks and talks about a law would seem to assume a particular understanding of this law on the part of this same person. It would seem to assume an understanding of the law as being fairly complex. ${ }^{23}$ If we denote as $\mathrm{X}$ and $\mathrm{Y}$ the number of identifying criteria and legal consequences tied to the concept represented by a conceptual term, the economizing effect of using a concept like legal ownership can be described as the difference between (X.Y) and $(\mathrm{X}+\mathrm{Y}) .{ }^{24}$ Consequently, the economizing effect of uttering a conceptual term would seem to require an assumption that $\mathrm{X} \geq 2$ and $\mathrm{Y} \geq 2$ and that either $\mathrm{X}>2$ or $\mathrm{Y}>2$.

In the example of Danish property law, this requirement is certainly met. The usage of the term legal ownership economizes the verbal expression of the relevant law since we assume that according to Danish law, legal ownership in a piece of property can be accomplished in three different ways, each one independently of the others; and because we assume that independently of how a piece of property was acquired, legal ownership will have four

\footnotetext{
${ }^{21} \mathrm{cf}$, eg, Blakemore (n 7) at 102-103.

22 ibid ch 1.

23 cf Torben Spaak, 'Alf Ross on the Concept of a Legal Right', at $8<$ http://ssrn.com/abstract=923433> accessed on 11 December 2013 (forthcoming in Ratio Juris 2013).

${ }^{24}$ cf Lars Lindahl, 'Deduction and Justification in the Law: The Role of Legal Terms and Concepts, (2004) 17 Ratio Juris 182, 190.
} 
different legal consequences. However, if we would have used instead as our example a law that we perceived as less complex, such as for instance the international law of the high seas outlined below, ${ }^{25}$ the situation would be quite different. Obviously, in this example, the usage of a term such as the high seas does not have an economizing effect:

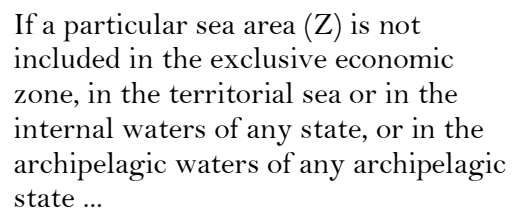

state ...
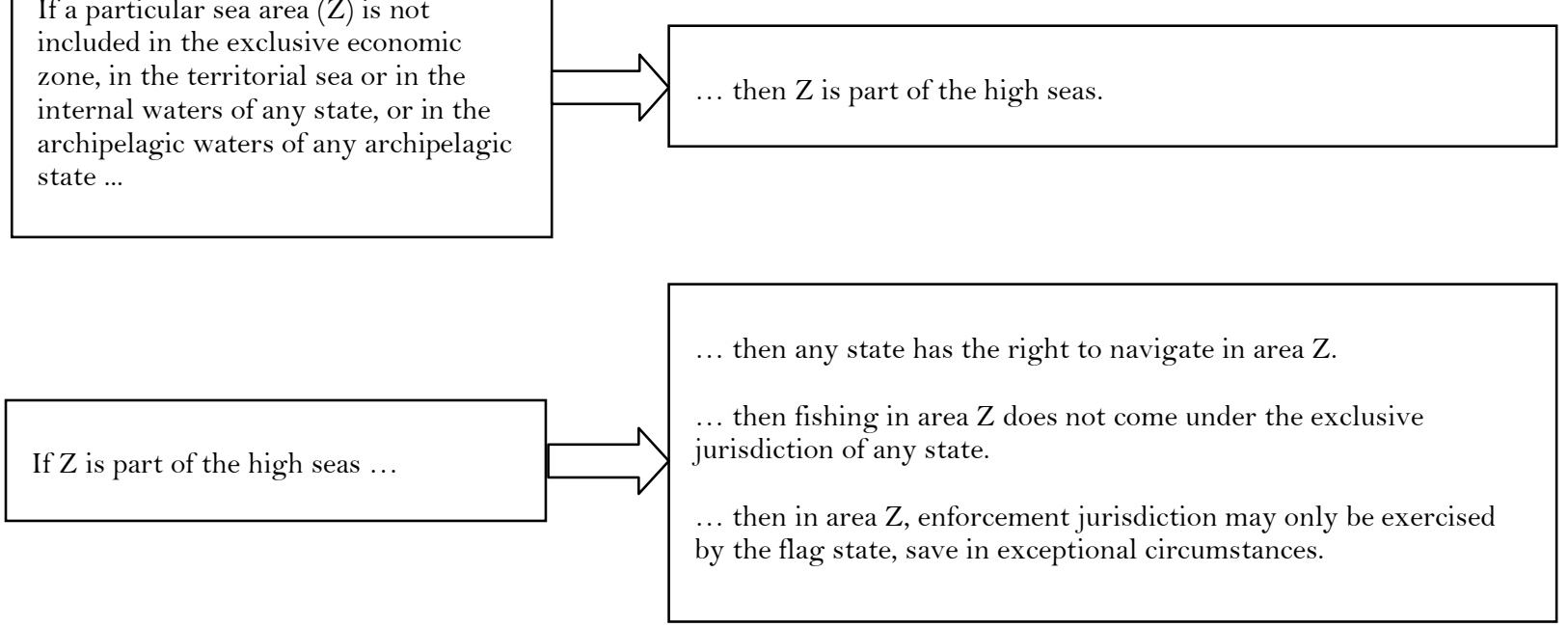

This is why I suggest that conceptual terms have only an economizing functionality. Conceptual terms may help participants in international legal discourse think and talk about international law in a more economic fashion. Without knowing anything about the particular contexts drawn upon for the purpose of understanding of a conceptual term, we can only say what it potentially does.

\section{THE NORMATIVE FUNCTIONALITY OF CONCEPTUAL TERMS}

International law is not a self-contained normative system. When international lawyers think about how to verbally represent a concept that they wish to introduce in international legal discourse, rather than inventing an entirely new term, they often find it convenient and appropriate to draw on terminology already used in neighbouring moral or political discourses. Such borrowing may be more or less explicit. Sometimes, concepts are expressed in language imitating exactly a conceptual term used in moral or political discourse. This often has the effect of seriously confusing discussion of the relevant legal issues. For example, when in 2010 the Swedish Parliament recommended that the Swedish Government recognizes the 1915 genocide of Armenian, Assyrian, and Greek populations during Ottoman reign of Turkey, ${ }^{26}$ the layman had a difficult time understanding whether recognition concerned the commission of genocide in a legal or a political sense. Sometimes, international lawyers explicitly emphasize that although they may have borrowed a term from moral or political discourse, the concept now represented by that term is unique to international law. Such a clarification can be accomplished by adding language that qualifies in some way or another the language normally used in the relevant non-legal discourse. For example, Article 21 of the Articles on Responsibility of States for Internationally Wrongful Acts

\footnotetext{
${ }^{25} \mathrm{cf}$ Part VIII of the United Nations Convention on the Law of the Sea (adopted 10 December 1982, entered into force 16 November 1994) 1833 UNTS 3.

26 Decision of 11 March 2010, available through the official webpage of the Parliament: <http://www.riksdagen.se> search-path 'Debatter och beslut' > '2009/10:UU9' accessed on 11 December 2013.
} 
does not refer to self-defence only, but to 'self-defence taken in conformity with the Charter of the United Nations'. ${ }^{27}$ Clarification can also be accomplished by the adoption of a definition of the concept for legal purposes. For example, in Article 101 of the 1982 UN Convention on the Law of the Sea, the concept of piracy is defined as follows:

Piracy consists of any of the following acts:

(a) any illegal acts of violence or detention, or any act of depredation, committed for private ends by the crew or the passengers of a private ship or a private aircraft, and directed:

(i) on the high seas, against another ship or aircraft, or against persons or property on board such ship or aircraft;

(ii) against a ship, aircraft, persons or property in a place outside the jurisdiction of any State;

(b) any act of voluntary participation in the operation of a ship or of an aircraft with knowledge of facts making it a pirate ship or aircraft;

(c) any act of inciting or of intentionally facilitating an act described in subparagraph (a) or (b).

To the extent that conceptual terms are constructed for the purpose of international law on the basis of concepts used in moral or political discourses, this adds to the functionality of those terms. ${ }^{28}$ In moral and political discourses, concepts are used in normative inference schemes, too. In political discourse, for instance, the concept of genocide is linked to norms that condemn acts of genocide in the strongest possible terms. ${ }^{29}$ Typically, when international legal language borrows from moral or political discourse, the legal terminology will inhere some of this normativity. The normative significance of the conceptual term used in legal discourse will turn, not on the normativity of law as such, but rather on the normativity associated with the moral or political concept or concepts drawn upon. That being the case, using concepts as intermediate links in legal inferences may work to provoke reactions that international law itself cannot provoke. It may help international lawyers convince their audiences of the correctness of their arguments. For instance, depending on whether the systematic killing of a group of people is categorised as genocide, or as a mere breach of an international legal obligation tied to legal consequences like compensation and satisfaction, typically, the commission of the crime will provoke more or less detest. Similarly, the maintenance of a situation or a practice will typically provoke different reactions depending on whether we refer to it as war or armed conflict, as targeted killing or as the extrajudicial killing of unlawful combatants, as a reprisal or a counter-measure, as expropriation or the taking of property, etc. This is what I refer to as the normative functionality of conceptual terms in international law.

The normative functionality of a conceptual term uttered in international legal discourse may be more or less obvious to a legal audience. When concepts are expressed using 'primarily evaluative language', ${ }^{30}$ their moral/political normativity should be obvious to anyone. Examples include conceptual terms such as equitable principles, ${ }^{31}$ due diligence, ${ }^{32}$ fair

\footnotetext{
27 See UNGA Res 56/83 (12 December 2001).

${ }^{28}$ See eg Lindahl (n 24) at 195-198; Lorenz Kähler, 'The Influence of Normative Reasons on the Formation of Legal Concepts' in Jaap Haage and Dieter von der Pfordten (eds), Concepts in Law (Springer 2009) 81-97.

$29 \mathrm{cf}$ the Preamble to the 1948 Convention on the Prevention and Punishment of the Crime of Genocide (adopted 9 December 1948, entered into force 12 January 1951) 78 UNTS 277.

${ }^{30}$ Compare Richard Mervyn Hare, Essays in Ethical Theory (OUP 1993) 116, 122.

${ }_{11}$ See eg North Sea Continental Shelf Cases (Germany v Denmark, Germany v The Netherlands) (Judgement) [1969] ICJ Rep 3, at 46-47.
} 
and equitable treatment, ${ }^{33}$ a reasonable period of notice, ${ }^{34}$ and just satisfaction. ${ }^{35}$ The moral or political normativity of most conceptual terms uttered in international legal discourse is more subtle, however. To illustrate, let us take once again the concept of genocide. The uttering of genocide will not provoke any particular reaction on the behalf of participants in international legal discourse just because they know the lexical meaning of that word. The normative functionality of genocide is dependent on the fact that participants in international legal discourse are acquainted with the underlying political discourse, at least to some extent.

For an even better example where the uttering of a conceptual term very discreetly adds to the normativity of international law, consider the principle of proportionality. Article 8 of the European Convention for the Protection of Human Rights and Fundamental Freedoms reads as follows:

1. Everyone has the right to respect for his private and family life, his home and his correspondence.

2. There shall be no interference by a public authority with the exercise of this right except such as is in accordance with the law and is necessary in a democratic society in the interests of national security, public safety or the economic well-being of the country, for the prevention of disorder or crime, for the protection of health or morals, or for the protection of the rights and freedoms of others. ${ }^{36}$

If a public authority interferes with the exercise of the right to respect for private and family life, obviously, in order not to be contrary to the Convention, the interference has to be necessary in a democratic society for the protection of national security, public safety, or any other of the interests specifically stated in paragraph 2. As shown by the practice of the European Court of Human Rights, in order to be able to decide whether a particular act of interference is necessary in the sense of the Convention or not, the Court has to determine the relative weight of the particular interests in conflict. Typically, this act of weighing presupposes some very difficult ethical considerations. Let us say, for instance, that the social authorities of a country decide to transfer the custody of a child from its natural to its foster parents and to impose severe visiting restrictions upon the former. ${ }^{37}$ In this case, weighing involves, on the one hand, the mutual interest of natural parents and children of developing a family relationship, and the psychological harm risked by the absence of an opportunity of developing such a relationship. ${ }^{38}$ On the other hand, weighing involves the potential harm caused to a child's personal development if depraved of a stable and harmonious living environment. ${ }^{39}$ In a case like this, by invoking 'the principle of proportionality', and by referring to the outcome of the consideration as proportionate, the

${ }^{32}$ See, eg, UNCHR, Report of the Special Representative of the Secretary-General on the Issue of Human Rights and Transnational Companies and Other Business Enterprises, John Ruggie (21 March 2011) UN Doc $\mathrm{A} / \mathrm{HRC} / 17 / 31$, at 16 .

${ }_{33}$ See eg art 2, para. 2 of the Agreement between the Government of the Kingdom of Sweden and the Government of Ukraine on the Promotion and Reciprocal Protection of Investments, concluded at Kiev, on 15 August 1995, SÖ 1996:38.

34. See eg Case Concerning Military and Paramilitary Armed Activities In and Against Nicaragua (Nicaragua $v$ United States of America) (Jurisdiction and Admissibility, Judgment) [1984] ICJ Rep 392, at 420.

${ }^{35} \mathrm{cf}$ art 41 of the Convention for the Protection of Human Rights and Fundamental Freedoms (European Convention for the Protection of Human Rights, as amended) (ECHR).

${ }^{36}$ ECHR.

${ }^{37} \mathrm{cf}$ Olsson v. Sweden (No. 2) [1992], Publications of the European Court of Human Rights, Series A no 250.

38 ibid, paras 87-91.

39 ibid, paras $87-91$. 
Court would typically have an easier time convincing its audience of the correctness of the weighing result. Arguably, by saying that an interference with the exercise of a right to respect for family life is proportionate, typically, the Court will provoke a more favourable reaction than by just saying that the one conflicting interest overrides the other. It will do so because in political discourse, the concept of proportionality is tied to norms that value the equal respect of the interests of all human beings and the means-end rationality of governmental interference with private life.

\section{THE CAMOUFLAGING FUNCTIONALITY OF CONCEPTUAL TERMS}

As noted in section 3, conceptual terms have an economizing functionality. If legal ownership had not existed, Danish property law would have to be stated and discussed linking individual identifying criteria with individual legal consequences, just like in the twelve-rule example provided in section 3. Speaking about Danish property law generally, lawyers would have to produce at each and every single occasion of utterance a complete list of all the relevant identifying criteria and all the relevant legal consequences. To this extent, obviously, conceptual terms potentially help lawyers think and talk about law in a more economic fashion.

The economizing functionality of conceptual terms comes at a certain price, though. Imagine a situation where the relevant identifying criteria and legal consequences are largely unknown to an utterer. The utterer may not have access to the relevant means for the determination of law. This is typically the case when an international agreement has been drafted in vague and indeterminate language, and there is no earlier or subsequent practice that may assist utterers in the interpretation of the agreement. In the alternative, although the utterer may have access to the relevant means for the determination of law, a scrutiny of those means may show that there is in fact no or very little agreement about the relevant identifying criteria or legal consequences. In all such cases, the uttering of a conceptual term may help to conceal that the utterer is in fact not in possession of the relevant legal knowledge. The conceptual term potentially camouflages the true nature of the inference involved, being in fact consequential more on the personal preferences of the utterer than on the utterer's observation and assessment of the relevant means for the determination of law. ${ }^{40}$ This is what I choose to refer to as the camouflaging functionality of conceptual terms.

My pet example is peremptory international law (jus cogens). Article 53 of the 1969 Vienna Convention on the Law of Treaties provides what seems to be currently accepted by international lawyers as the general applicable definition of the jus cogens concept. ${ }^{41}$ Notably, Article 53 defines jus cogens by stating the relevant legal consequences:

[A] peremptory norm of general international law is a norm accepted and recognized by the international community of States as a whole as a norm from which no derogation is permitted and which can be modified only by a subsequent norm of general international law having the same character.

It does so for a particular reason. In the process eventually leading up to the adoption of final Article 53, the drafters early decided to abstain from enumerating norms having the character of jus cogens; for several reasons. ${ }^{42}$ First, they feared that if particular norms of $j u s$

${ }^{40} \mathrm{cf}$ Lindahl (n 24) at 190-191.

${ }^{41} 1155$ UNTS 331.

${ }^{42}$ See Report of the International Law Commission on the Work of its Fifteenth Session (6 May - 12 July 1963) UN

Doc. A/CN.4/163, 199. Several members of the ILC suggested that a list of examples be given. See ibid. 
cogens were enumerated, this might lead to misunderstandings as to the position of norms not enumerated. ${ }^{43}$ Secondly, and even more importantly in this context, enumerating norms of jus cogens was a near-impossible task since there was no common agreement among international lawyers about the particular criterion or criteria to be used for the identification of such norms. ${ }^{44}$

The situation has hardly changed over the more than 40 years that have passed since the adoption of the Vienna Convention. International lawyers are still in vast disagreement about the particular criterion or criteria to be used for the identification of jus cogens norms. Commentators speculate about the particular reason for this disagreement. The relevant explanation seems to lie partly in the simple fact that lawyers have widely different opinions about the ultimate justification of the international jus cogens regime. ${ }^{45}$ Depending on who we ask, that person will struggle to convince us that jus cogens derives from natural law; ${ }^{46}$ that jus cogens is an 'international constitution'; ${ }^{47}$ that jus cogens is the expression of an 'international ordre public; ; ${ }^{48}$ that jus cogens safeguards 'the common good of the international community', ${ }^{49}$ or that jus cogens serves to protect some more specific objective such as an 'open international market'. ${ }^{50}$ Partly, the explanation seems to lie in the fact that the reasons invoked in justification of the international jus cogens regime are themselves essentially contested. Even assuming that two lawyers agree that the ultimate justification of the jus cogens regime lies in its protection of the international ordre public, those two lawyers will typically have very different ideas of what the international ordre public actually stands for.

As some philosophers would put it, the jus cogens concept remains essentially contested. ${ }^{51}$ Still, the jus cogens concept exists; it is remarkably present in international legal discourse. If the jus cogens concept had not existed, the relevant law would have to be stated and discussed linking particular identifying criteria with particular legal consequences. That would have revealed the essentially contested character of the matter, since no or very few such identifying criteria would have mustered agreement. By the introduction of jus cogens in the inference from identifying criteria to legal consequences, and because of the particular construction of Article 53, this fact is largely concealed. Obviously, states can be generally agreed that legal consequences like non-derogation and non-modification by ordinary international law should ensue from the application of a particular norm of law, although they may have widely different explanations to why those legal consequences should ensue. This makes jus cogens one of the best possible examples of the camouflaging functionality of conceptual terms in international law.

\footnotetext{
${ }^{43}$ Report of the International Law Commission on the Work of its Eighteenth Session (4 May - 19 July 1966) UN Doc. A/CN.4/191, 248.

${ }^{44}$ See Report of the International Law Commission on the Work of its Fifteenth Session (6 May - 12 July 1963) UN Doc. A/CN.4/163, 198.

${ }^{45}$ See Ulf Linderfalk, 'What Is so Special About Jus Cogens?: On the Distinction between the Ordinary and the Peremptory International Law', (2012) 14 Intl Community L Rev 3, at 9-11.

${ }^{46}$ See eg Dan Dubois, 'The Authority of Peremptory Norms in International Law: State Consent or Natural Law?’ (2009) 78 Nordic J Intl L 133-175.

${ }^{47}$ See eg Susan Breau,'Review Essay: The Constitutionalization of the International Legal Order', (2008) 21 Leiden J of Intl L 545, at 550 .

${ }^{48}$ See, eg Alexander Orakhelashvili, Peremptory Norms in International Law (OUP 2006) 7 ff.

${ }^{49}$ See eg Alan Brudner, 'The Domestic Enforcement of the International Covenant on Human Rights', (1985) $35 \mathrm{U}$ of Toronto L J 219, at 249.

50 See eg Michael Allen, 'Globalization and Peremptory Norms in International Law: From Westphalia to Global Constitutionalism’, (2004) 41 Intl Politics 341, at 346.

${ }^{51}$ See Walter Bryce Gallie, 'Essentially Contested Concepts', (1956) 56 Proceedings of the Aristotelian Society 167-198.
} 


\section{THE DISCLOSING FUNCTIONALITY OF CONCEPTUAL TERMS}

For the same reason as a conceptual term may work to camouflage the true nature of the particular legal inference expressed by an utterer in using that term, it may work to disclose and emphasize the nature of such an inference. A good example of this is the concept of an internationally wrongful act of a state. The international law of state responsibility distinguishes between breaches of international legal obligations and internationally wrongful acts of a state. According to Article 1 of the Articles on Responsibility of States for Internationally Wrongful Acts, '[e]very internationally wrongful act of a State entails the international responsibility of that State'. In Article 2, the concept of an internationally wrongful act of a state is defined as an action or omission, which '[i] $]$ s attributable to the State under international law', and which '[c]onstitutes a breach of an international legal obligation of the State'. Pursuant to Articles 1 and 2, if an act or omission is attributable to a state and it amounts to a breach of an international obligation of that state, international responsibility ensues. There is an exception to this rule, however. According to Articles 2025 , circumstances may be such as to preclude the wrongfulness of an act or omission, in which case international responsibility does not ensue. For example, according to Article 25, necessity will preclude the wrongfulness of an act not in conformity with an international obligation of a state, if the act '[i]s the only way for the State to safeguard an essential interest against a grave and imminent peril'. ${ }^{52}$

With this legal setting in fresh memory, let us assume a situation where necessity precludes the wrongfulness of a breach of an international legal obligation owed by one state to another. Let us assume the circumstances of the Torrey Canyon incident. In 1967, a Liberian tanker ship carrying large amounts of crude oil ran aground off the coast of the United Kingdom, in the high seas. The accident caused considerable oil spills threatening to severely damage the coastline and the marine environment. UK authorities decided to bomb the ship. That caused the remaining oil to burn, thereby containing the damages considerably. Since Liberia had not consented to the operation, the measures taken by UK authorities were in breach of the principle of exclusive flag state jurisdiction. According to the applicable rule of customary international law, '[s] hips shall sail under the flag of one State only and [...] shall be subject to its exclusive jurisdiction on the high seas'. ${ }^{53}$ The international wrongfulness of the breach was precluded, however, since bombing was the only way for UK authorities to safeguard an essential interest against a grave and imminent peril. In the words of Article 25 of the Articles on Responsibility of States for Internationally Wrongful Acts, bombing was 'necessary'.

The legal reasoning involved can be described in two different ways. First, it can be described by the direct linkage of particular identifying criteria with particular legal consequences, just like in the twelve-rule example given in section 3 :

If UK authorities drop a bomb on the Torrey Canyon, this being the only way for the United Kingdom to safeguard an essential interest against a grave and imminent peril, then the operation shall be considered to not entail the international responsibility of the United Kingdom.

\footnotetext{
${ }^{52}$ For the sake of presentation, I have taken the liberty of using a slightly abbreviated version of art 25.

${ }_{53}$ See art 6 of the Geneva Convention on the High Seas (adopted 29 April 1958, entered into force 30 September 1962) 450 UNTS 11.
} 
Secondly, the reasoning can be described in the way of the international law of state responsibility, by the insertion of the concept of an internationally wrongful act of a state as a connective between legal facts and legal consequences:

If UK authorities drop a bomb on the Torrey Canyon, this being the only way for the United Kingdom to safeguard an essential interest against a grave and imminent peril, then the operation shall be seen to not constitute an internationally wrongful act of a state.

If the dropping of a bomb by UK authorities on Torrey Cayons does not constitute an internationally wrongful act of a state, then the operation shall be considered to not entail the international responsibility of the United Kingdom.

As it seems, the latter description of international law is more true to reality. Obviously, when Torrey Canyon ran aground, and considerable oil spills threatened to damage the marine environment, UK authorities were forced to make a decision. They had to decide whether to bomb and promote the interest of a clean environment, or whether not to bomb and promote the interest of freedom of navigation. From the perspective of the law of state responsibility, the decision made little difference. Whether UK authorities decided to bomb or not, international responsibility would not ensue. Inevitably, the decision was determined by other considerations than law. It was determined by ethical considerations. This fact is revealed only in the latter of the two descriptions of the relevant law. By the insertion of the concept of an internationally wrongful act of a state as a connective between legal facts and legal consequences, a gap will remain between a breach of an international legal obligation and an internationally wrongful act of a state. This gap will make apparent the ethical choices often involved in the application of international law: in our example, the choice between promoting the interest of a clean environment and promoting the interest of freedom of navigation. This is why I find it appropriate to speak about the disclosing functionality of the concept of an internationally wrongful act of a state.

\section{THE SYSTEMIZING FUNCTIONALITY OF CONCEPTUAL TERMS}

According to the ontology adopted in this essay, a concept is the generalized idea of an empirical or normative phenomenon or state of affairs or a class of such phenomena or states of affairs. As implied by the word 'generalized', concepts are formed through a process of abstraction. They are the result of the ability of the human brain to perceive of particular properties of phenomena as characteristics shared by all entities belonging to the extension of some certain concept. ${ }^{54}$ For example, footballs are round or oval in shape; they are made by leather or plastic; they have a weight of something between 410 and 450 gram. Similarly, the nationality of a ship is an entitlement granted to a ship-owner by a state. ${ }^{55}$ High seas are all parts of the sea that are not included in the exclusive economic zone, in the territorial sea or the internal waters of a state, or in the archipelagic waters of an archipelagic state. ${ }^{56} \mathrm{~A}$ jus cogens norm is a norm accepted and recognized by the international community of states as a whole as a norm from which no derogation is permitted and which can be modified only by the creation of a new norm of jus cogens. ${ }^{57}$

By its mere nature, obviously, a conceptual term will always express an assumption about the existence of some certain relationship or relationships between particular phenomena or

\footnotetext{
${ }^{54}$ Compare Laurence and Margolis (n 3) 3-81.

${ }_{55}$ Compare art 91 of the United Nations Convention on the Law of the Sea (n 25).

${ }^{56}$ Compare art 86 of the United Nations Convention on the Law of the Sea (n 25).

${ }^{57}$ See art 53 of the 1969 Vienna Convention on the Law of Treaties.
} 
states of affairs. ${ }^{58}$ For instance, if two different norms $\left(\mathrm{N}_{1}\right.$ and $\left.\mathrm{N}_{2}\right)$ are referred to by a particular person as jus cogens, then this person commits himself to the assumption that there is a relationship between $\mathrm{N}_{1}$ and $\mathrm{N}_{2}$ that does not obtain between any of those two norms and a norm belonging to the ordinary international law. Such an assumption implies systemization. When a person categorizes a particular phenomenon or state of affairs as one that comes within the extension of some particular concept, the phenomenon is fitted into the greater system of assumptions available to that person at the relevant point in time. Relationships are established between the person's observation of the particular phenomenon or state of affairs and the set of assumptions held by that person about the world at large. This explains why conceptual terms may help participants in international legal discourse think and talk more systematically about legally relevant data. I will illustrate this proposition using as my example the concept of an act of a state.

Let us assume the facts of the Case Concerning Military and Paramilitary Armed Activities In and Against Nicaragua. ${ }^{59}$ According to the rule of the prohibition of the use of force, the laying of mines by one state in the territorial waters of another state is prohibited. A group of private individuals - in the terminology of the CIA, a group of 'Unilaterally Controlled Latino Assets' (UCLA's) - has engaged in the laying of mines in the territorial waters of Nicaragua. In so doing, they have acted on the instructions of a public authority of the United States: the CIA. Even worse, they have acted under the direction and control of that same authority. Since, according to Article 1 of the Articles on Responsibility of States for Internationally Wrongful Acts, '[e]very internationally wrongful act of a State entails the international responsibility of that State, ${ }^{60}$ the mine laying operation conducted by the UCLA's entails the international responsibility of the Unites States. This conclusion follows from the application of the relevant rules of customary international law reflected in Articles 4-11 of the Articles on Responsibility of States for Internationally Wrongful Acts. Articles 4-11 provide the criteria, by which an action or omission shall be identified as an act of a State. According to Article 8, "[ $[\mathrm{t}]$ he conduct of a person or group of persons shall be considered an act of a State under international law if the person or group of persons is in fact acting on the instructions of, or under the direction or control of, that State in carrying out the conduct'.

The relevant law can be described in two different ways. First, it can be described by the direct linkage of particular identifying criteria with particular legal consequences.

If a group of UCLA's engages in the laying of mines in the territorial waters of Nicaragua, and that group of UCLA's in fact acts under the instructions of the CIA, or under its direction or control, then the conduct in question entails the international responsibility of the United States.

Secondly, the relevant law can be described in the way of the Articles on Responsibility of States for Internationally Wrongful Acts, by the insertion of the concept of an act of a state as a mediating link between identifying criteria and legal consequences.

If a group of UCLA's engages in the laying of mines in the territorial waters of Nicaragua, and that group of UCLA's in fact acts under the instructions of the CIA, or under its direction or control, then that conduct shall be considered an act of the United States.

\footnotetext{
${ }^{58}$ Compare Laurence and Margolis (n 54) 3-81.

${ }^{59}$ Judgment of 27 June 1986, ICJ Reports, 1986, p. 14.

${ }^{60}$ Italics are added.
} 
If the laying of mines by a group of UCLA's in the territorial waters of Nicaragua is considered an act of the Unites States, then the conduct in question entails the international responsibility of the Unites States.

From the point of view of the systemization of international law, the latter description is certainly preferable. The former description has its virtues, of course. Among other things, it communicates openly the systemic character of international law: a legal rule is an ideal construction in the lawyer's model of a legal system. Hence, the full contents of a rule of international law will often have to be reconstructed on the basis of different rule fragments gathered at different locations in international legal discourse. ${ }^{61}$ In this case, whereas one fragment of the relevant rule originates in the law on the use of force, another originates in the law of state responsibility. If rule fragments, in order to appear meaningful, have to be accumulated and combined, then obviously there must be structures determining how this task shall be accomplished, provided of course that we do not accept just any combination of fragments. Just like the legal rules themselves, these structures form part of the international legal system.

The flaw of the former description lies with its predominant interest with the more concrete dimensions of law. By concretizing law, the description obscures a point of importance, namely that there is a relationship between, on the one hand, Article 8 of the Articles on Responsibility of States for Internationally Wrongful Acts, and on the other hand, the prevailing conceptualization of the state. Due to their mere nature, in much of its international relations states have to rely on real, physical human beings, who act as intermediaries. In the latter description of the relevant international law, this relationship is brought out more clearly. The concept of an act of a state works as a link between the abstract and the more concrete dimensions of law. It makes explicit that legal argumentation is a two-way process. Lest coherence of international law is to be lost entirely, legal reasoning will have to keep zigzagging back and forth between the concrete and the abstract dimensions of law. The development of the concept of an act of a state is dependent on the existence and development of the relevant provisions in the law of state responsibility on the attribution of conduct to a state. Similarly, the existence and development of the provisions on the attribution of states is dependent on the existence and development of the concept of an act of a state. By clarifying this relationship, the concept of an act of a state facilitates constructive discussions concerning the state as legal subject and internationally responsible person. Obviously, in the example provided, with the latter description of the relevant law rather than the former, questions such as the following will come more naturally: To what extent should a state be allowed to act through private intermediaries?

\section{THE FORMATIVE FUNCTIONALITY OF CONCEPTUAL TERMS}

As noted in section 7, by their mere nature, conceptual terms express an assumption about the existence of some certain relationship or relationships between particular phenomena or states of affairs. This is why conceptual terms help participants in international legal discourse think and talk more systematically about legally relevant data. We may now add to this description the following interesting observation: conceptual terms are themselves systematically ordered. As indicated in section 7, the categorization of a particular phenomenon by a particular person $(\mathrm{P})$ as one that comes within the extension of a particular concept, such as for instance football, will inevitably depend on the relationships

${ }^{61}$ Compare Ulf Linderfalk, 'The Effect of Jus Cogens Norms: Whoever Opened the Pandora's Box, Did You Think About the Consequences?', (2007) 18 EJIL 853-871 
between P's observation of the phenomenon and the set of assumptions held by $\mathrm{P}$ about the world at large. Similarly, the meaning of a conceptual term will always be dependent on its relationship with other conceptual terms belonging to the same language system. ${ }^{62}$ Obviously, the meaning of football (in the sense of the ball object) will be dependent on its relationship with the concept of the game known as football. The meaning of the colour cherry red will be dependent on its relationship with similar colours such as maroon or burgundy. The meaning of holiday will be dependent on its relationship with workday. Similar relationships exist between conceptual terms like daffodil and flower; arm and body; minute and second; big and small; kick and foot; raisin and grape; etc.

If relationships exist between different conceptual terms, then this implies the existence of principles that can explain those relationships. Just like there are criteria that can be used to explain the distinction between footballs and non-footballs, there must be principles that can explain why for instance, according to most people, grape is more closely related to raisin than to leisure car. ${ }^{63}$ Because of the existence of such principles, the introduction of a new conceptual term in international legal discourse potentially works to facilitate the formation of yet other concepts. This is what I refer to as the formative functionality of conceptual terms. Examples are not difficult to find. Referring to an entity meeting some certain criteria as a sovereign state obviously helps international lawyers conceive of other particular phenomena and states of affairs, or classes of such phenomena or states of affairs, as for instance acts of state, sovereign immunities, flag states, state boundaries, nationality, state recognition, and state succession. Referring to a phenomenon meeting some certain criteria as a norm of jus cogens helps international lawyers conceive of other particular phenomena as ordinary international law. Similarly, the existence of the concept of a means of interpretation owes partly to the practice of referring to a category of activities as interpretation. The existence of the concept of a diplomatic agent owes partly to the practice of referring to particular groups of people and their assigned tasks as diplomatic missions. The existence of the concept of hot pursuit owes partly to the practice of referring to particular phenomena as foreign ships, which in turn owes partly to the practice of referring to a particular state of affairs as the nationality of a ship.

\section{FUNCTIONALITY ANALYSIS}

Given the examples provided in sections 3-8, it would seem to be a truism, first, that single conceptual terms may often (if not always) have more than one functionality, and secondly, that the functionalities of two terms, when randomly chosen, are often not the same. Consequently, when international lawyers wish to determine the functionalities of conceptual terms, this has to be done on a case-by-case basis. Considering this, any suggestion as to what might be the functionality or functionalities of a particular term in international legal discourse is bound to raise methodological questions. In what sense can the functionality of a conceptual term be determined? Stated instead in a context of justification, ${ }^{64}$ how can a person ensure that her suggestion as to what might be the functionality or functionalities of a particular term will be considered by others as sound, and not as the result of mere speculation?

\footnotetext{
${ }^{62}$ See Lyons (n 8) ch 8-9.

63 ibid.

${ }^{64}$ On this terminology, see Karl Popper, The Logic of Scientific Discovery (Hutchinson 1959). In the context of law, see Martin Golding, 'A Note on Discovery and Justification in Science and Law' (1986) 27 Justification 124-140.
} 
My answer to this question is implicit in the earlier sections of this essay, and more particularly in the set of examples that I provided in section 3-8. In section 3, I warned readers not to confuse the functionality of a conceptual term with the actual function or effect of its utterance. In the terminology of this essay, the functionality of a conceptual term is its meaning potential. So defined, when a conceptual term is being uttered, the functionality of that term may help affect the beliefs, attitudes, or behaviour of the addressee in some particular way, but the actual effect will never be guaranteed. As I explained, this is because the actual effect will always be dependent on a particular context. To illustrate this proposition, I used the example of Jane and John. Jane utters to her husband John, who is on his way out: 'It's raining!' Certainly, this sentence may be used to cause John to think that perhaps he should help Jane move tables from the garden and lay them inside. However, in order for Jane's utterance to actually have this effect, John has to entertain some certain assumption, such as for instance the assumption that Jane is throwing a garden party later that day.

Now, what sections 3-8 made sufficiently clear is the fact that the functionality of a conceptual term is also context-dependent, although in a different sense. The actual effect of an utterance of a conceptual term depends on whether some particular assumption was actually used by a particular addressee in the process of understanding it. The functionality of a conceptual term is dependent on whether some certain kind of assumption is available to some certain potential addressee or addressees, in this case, participants in international legal discourse. ${ }^{65}$ To illustrate, as stated in section 4, the normative functionality of genocide is dependent on the fact that participants in international legal discourse to some extent can acquaint themselves with the underlying political discourse. This is another way of saying that the normative functionality of genocide presupposes the availability of an assumption about the moral or political norms tied to the concept of genocide. If an assumption about those moral or political norms is not available to participants in international legal discourse, then the term genocide can never help utterers convince others of the correctness of their legal inferences, not even potentially. To facilitate reference, in referring to the entire set of assumptions available to a participant in international legal discourse, henceforth in this essay, I will use the term cognitive environment. ${ }^{66}$

Other functionalities can be similarly analyzed. The camouflaging functionality of jus cogens presupposes a cognitive environment that comprises the (possibly false) assumption that the utterer can provide a fairly good description of the identifying criteria and the legal consequences tied to the jus cogens concept. The disclosing functionality of an international wrongful act of a state presupposes a cognitive environment that does not comprise an assumption about the ethical choices often involved in the application of the international law of state responsibility. The systemizing functionality of an act of a state presupposes a cognitive environment that comprises an assumption about the relationship between the concept of a state and the relevant law of state responsibility on the attribution of conduct. The formative functionality of hot pursuit presupposes a cognitive environment that comprises an assumption about the relationship between the concept of hot pursuit and the concept of a foreign ship.

Thus, the examples provided in sections 3-8 suggest that the analysis of the functionality of particular conceptual terms in international legal discourse be done according to some certain methodology. Let us assume I wish to inquire whether a given conceptual term, such

${ }^{65}$ Compare Dan Sperber and Deirdre Wilson, Relevance, Communication and Cognition (Basil Blackwell 1986) 81-93.

66 ibid, $38 \mathrm{ff}$. 
as for instance investor, may help utterers convince participants in international legal discourse of the correctness of their arguments. According to the examples, the relevant way to conduct this inquiry would be by asking the following two questions:

(1) If the normative functionality of investor presupposes the availability of some certain kind of assumption, what is this assumption exactly?

(2) Is it fair to assume about the cognitive environment of participants in international legal discourse that it comprises this particular assumption?

As stated in the introductory section 1, throughout this essay, any inquiry following this methodology will be referred to as functionality analysis.

\section{ON THE USEFULNESS OF FUNCTIONALITY ANALYSIS}

Functionality analysis may inform the study of international law in many areas of investigation. To illustrate, take the example of the term proportionality. In several areas of international law, proportionality assessments are an integral part of the application of legal norms. Such assessments typically occur in areas of law where significant ethical values are at stake, and where those values do not easily lend themselves to quantification. On the face of it, it would seem that whenever proportionality assessments are made, decision-makers' primary focus is on the achievement of concrete justice rather than on the production of a principled decision based on rational reason. Not surprisingly, therefore, in the camp of international legal scholars, commentators have often been sceptical about the proportionality concept. ${ }^{67}$ Many commentators perceive of the concept as an excuse for decision-makers to impose on the application of law their own subjective values. In the opinion of commentators, if the term proportionality ever works as a description of anything, then what it describes is certainly not the law. ${ }^{68}$ In the face of this criticism, and considering how widely shared proportionality scepticism actually is, one would expect resort to the term proportionality in international legal discourse to be on decline. In reality, the trend is going in the exact opposite direction. Proportionality is gaining, not losing, popularity. ${ }^{69}$ Two questions arise: (1) How can the increased usage of proportionality in international legal discourse be explained? And (2) what is the further significance of the proportionality lingo'? As I will now argue, functionality analysis helps providing both questions with an answer.

The first question pertains to the motivating force of utterers. How can we explain that participants in international legal discourse (including proportionality skeptics) continue to use proportionality in the communication of legal propositions, if this term does not describe a relationship between identifying criteria and legal consequences? For proponents of the descriptive theory of meaning, this question poses a problem. If there is no law that can be described by the usage of the term proportionality, then according to them, this term can

\footnotetext{
${ }^{67}$ For an excellent summary of the critique, see Jeremy Gunn, 'Deconstructing Proportionality in Limitations Analysis' (2005) 19 Emory Intl L Rev 465-474.

68 ibid.

${ }^{69}$ Symptomatically, proportionality is now used by disciplines such as for instance international environmental law and international investment law, where up to recently proportionality talk would have been considered anomalous. See eg Takeo Horiguchi, 'Proportionality as a Norm of Application for the Precautionary Principle: Its Significance for the Operation of the Precautionary Regime for Land-Based Marine Pollution in the North-West Atlantic' in Teruo Komori and Karel Wellens (eds), Public Interest Rules of International Law (Ashgate 2009) 165-188; Alec Stone Sweet, 'Investor-State Arbitration: Proportionality's New Frontier' (2010) 4 L \& Ethics of Human Rights <http://www.bepress.com/lehr/vol4/iss1/art4> accessed on 11 December 2013.
} 
only be categorized as non-sensical. Consequently, proponents of the descriptive theory of meaning can only answer by concluding that participants in international legal discourse wrongly believe proportionality to describe a law, and that will be the end of the matter. For proponents of a functionality-based theory of meaning, on the other hand, utterers may have many reasons for using a term such as proportionality. If it is established that proportionality assessments are in fact not done according to standards laid down in international law, proponents of a functionality-based theory of meaning will conclude that an asserting functionality probably cannot be ascribed to proportionality; and if it can, then at least the asserting functionality of proportionality cannot be the only explanation of the popularity of this term. Proponents of a functionality-based theory of meaning will then proceed to an investigation of the cognitive environment of participants in international legal discourse to see whether other functionalities can be ascribed to proportionality.

The second question pertains to the potential effect of legal utterances. International legal discourse being a necessary part of legally relevant activities - such as for instance the making of international law, the interpretation and application of international law, the description of international law, the systemization of international law, the critical assessment of international law, the pleading of a particular interpretation or application of international law, and the appeal for its revision - the question can be rephrased as follows: What is the potential effect of the usage of a conceptual term such as proportionality by some given participant in international legal discourse $(\mathrm{NN})$ on some given legal activity or activities (A)? As every international lawyers knows, this question cannot be answered by just referring to the fact that $\mathrm{NN}$ belongs to some certain category of agents. Legal discourse is an activity with no uniquely fixed roles. No particular category of agents can be identified with any one particular task. Certainly, most international lawyers would probably agree to the suggestion that it is a primary task of international judiciaries to interpret and apply the law. The fact is, however, that this task may also entail other lawrelated actions such as the systemization of the law; and the task does not prevent at least single judiciaries from also pleading a particular interpretation or application of the law, and in exceptional cases perhaps even criticizing the law. To give a few further examples, a legal scholar may describe and assess the law, but he or she may also criticize the law and argue for its revision. An expert collegium may be systemizing the law, but it may also be pleading a particular interpretation or application of the law or arguing its revision. As shown by the examples, the significance of the usage of a conceptual term has to be established by resort to other indicators than the mere fact that the utterer belongs to some certain category of agents. The potential meaning of the term works as such an indicator; and this is where functionality analysis enters the picture.

Functionality analysis helps answering questions concerning the significance of the usage of particular conceptual terms. First of all, functionality analysis helps international lawyers understand the relevance of contextual elements, such as for instance the particular place, time, or situation of utterance, or the particular topic addressed..$^{70}$ As stated in section 9, the functionalities of conceptual terms in international legal discourse are dependent on the cognitive environment of its participants. Now, obviously, the cognitive environment of participants in international legal discourse inevitably varies depending on the particular geographically, temporally, sociologically, or topically defined part of international legal discourse we happen to be investigating. The cognitive environment of participants in international legal discourse on 11 December 2013, for instance, is not necessarily the same as that on 11 September 2001. The cognitive environment of international lawyers based in Germany is not necessarily the same as that of lawyers based in the People's Republic of

${ }^{70} \mathrm{cf}$ Lyons (n 8) at $573 \mathrm{ff}$. 
China. The cognitive environment of a group of law students in a class room situation is not necessarily the same as that of experienced international lawyers and highly qualified academics at an international conference. The cognitive environment of lawyers engaged in a discussion of international human rights law is not necessarily the same as that of lawyers engaged in a discussion of matters concerning maritime delimitation. Functionality analysis acknowledges that differences of this kind may exist. It explains why the significance of the utterance of a conceptual term like proportionality sometimes will be one, and sometimes another.

Even more importantly, functionality analysis helps international lawyers understand the relationships that exist between the usage of a particular conceptual term and the effects that it may have on legal activities (referred to in this essay as the significance of the term). As appears from sections 3-8, those relationships do not always present themselves very clearly. This is because the uttering of a conceptual term may affect the beliefs, attitudes, or behaviour of an addressee in several ways simultaneously. ${ }^{71}$ For instance, proportionality has both a systemizing and a formative functionality, while it potentially not only helps international lawyers think and talk more systematically about legally relevant data, but also facilitates the formation of new concepts such as for instance proportionality assessment and proportionality principle. To complicate things even further, functionalities of conceptual terms may be indirect in the sense that if a cognitive environment comprises an assumption that a conceptual term has some certain functionality, then this may work to confer further functionalities on this same term. For instance, the utterance of proportionality may be used to camouflage the fact that in the final analysis, using traditional legal methodology, very little can be said about the identifying criteria and legal consequences tied to this concept. Because it has this functionality, proportionality potentially also renders the understanding and assessment of legal inferences more difficult.

Obviously, just as there may be a relationship between the lexical meanings of two words in a language (eg arm and body), relationships may exist between the different functionalities of a conceptual term. Functionality analysis may help explain those relationships. This may seem particularly important in cases where the internal structures of functionalities assume forms that are more complex than in the example just provided. Consider for instance the example of jus cogens. As I would like to believe, jus cogens potentially helps international lawyers inflate to importance statements that on closer scrutiny might be rather trivial: 'In my opinion, the prohibition of torture is jus cogens (because it is extremely important that torture be prevented).' Jus cogens potentially also prevents participants in international legal discourse from questioning the intents of an utterer: In my opinion, the prohibition of torture is jus cogens (and if by any chance you do not share this opinion, this shows you are pro-torture).' The explanation of those two functionalities lies in the combination of the normative and camouflaging functionalities of jus cogens. In other words, jus cogens potentially prevents participants in international legal discourse from questioning the intents of an utterer, not because jus cogens potentially helps the utterer convince her audience of the correctness of her conclusion, and not because jus cogens potentially camouflages that in the final analysis, using traditional legal methodology, very little can be said about the identifying criteria and legal consequences tied to this concept, but because jus cogens potentially does both.

\footnotetext{
71 ibid, at $735-736$.
} 


\section{CONCLUSIONS}

What is the way ahead? Obviously, functionality analysis opens new possibilities for the study of legal discourse. Considering this observation, it might seem tempting to initiate empirical investigations with a view to establishing a catalogue of the various functionalities conferred on conceptual terms in particular legal discourses. I would personally warn against all such attempts. By providing examples of the many functionalities of conceptual terms in international legal discourse, as I did in sections 3-8, I do not mean to imply that functionalities can ever be described exhaustively; on the contrary. I work on the assumption that the functionalities of conceptual terms in legal discourses are innumerable. I am convinced that even if I would confine my task to exhaustively enumerating the functionalities of particular terms, I would experience great difficulties. And if by chance I should ever succeed listing the functionalities of some particular conceptual term, considering the context-dependency of functionalities, that list would have a very limited durability, which would make it rather pointless. In my opinion, the main focus of any further inquiries should be on other tasks. Further studies should include the relationships that exist between functionalities of conceptual terms and the effects that the uttering of such a term may have on legal activities, particularly the formation of international law. A clear candidate for further investigation is also the relevance of contextual elements. If my researcher's instinct does not altogether mislead me, understanding the dependency of functionalities on contextual elements like time or topic-matter will prove instrumental to the understanding of the development of international law over time and the explanation of the existence of specialized international legal regimes. 